О.В. Никифоров ${ }^{1}$, С.І. Смик ${ }^{1}$, П.М. Мартиненко ${ }^{1}$, Ю.Б. Ситник ${ }^{2}$, А.С. Могилатенко ${ }^{3}$

${ }^{1}$ Харківський національний університет Повітряних Сил ім. І. Кожедуба, Харків

${ }^{2}$ Льотна академія Наџіонального авіаційного університету, Кропивницький

${ }^{3}$ Національний університет оборони Украйни ім. I. Черняховського, Київ

\title{
РОЗРАХУНОК ТАКТИЧНОГО РАДІУСА ДІЇ ЛІТАКІВ 3 ТУРБОРЕАКТИВНОЮ СИЛОВОЮ УСТАНОВКОЮ ПРИ СКОРОЧЕНОМУ НАБОРІ ВИХІДНИХ ДАНИХ
}

У статті представлено методику розрахунку тактичного радіуса дії літаків з турбореактивною силовою установкою на підставі їх льотно-технічних характеристик, щзо наводяться у загальнодоступній довідковій літературі. Це дозволяє розраховувати їх характеристики досяжності, не використовуючи громіздкі дані, щзо містяться у номограмах з розрахунку дальності та тривалості польоту літаків відповідних типів. При изьому забезпечується збіжність результатів, отриманих за допомогою запропо-

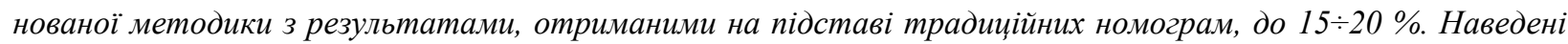
результати можуть бути використані при розробиі спеціального програмного забезпечення для систем моделювання бойових дій авіаиіï.

Ключові слова: інженерно-цтурманський розрахунок, тактичний радіус дї, профіль польоту, досяжність авіації, дальність та тривалість польоту, кілометрова витрата палива, годинна витрата палива.

\section{Вступ}

Постановка проблеми. При розробці спеціального програмного забезпечення в системах моделювання бойових дій виникає необхідність у визначенні радіусу бойових дій засобів повітряного нападу. Однією $з$ проблем є наявність лише суто обмеженої інформації щодо льотно-технічних характеристик (ЛТХ) літаків з бойового складу авіації противника. При цьому інженерно-штурманські розрахунки (ІШР) займають значне місце в процесах прийняття рішень стосовно дій авіації. До завдань, що вирішуються у рамках проведення ІШР, належать: розмітка та перевірка реалізованості маршрутів польоту по запасу палива, розрахунок тактичних радіусів дій авіації. Зазвичай, для вирішення перелічених завдань використовуються методики на основі номограм з розрахунку дальності і тривалості польотів літаків. Номограми складаються за результатами льотних випробувань різних типів i модифікацій авіаційної техніки.

Для автоматизації ІШР вдаються до оцифровування номограм дальності і тривалості польоту, що пов'язано зі значними витратами часу [1-2]. Доводиться мати справу з великим обсягом вихідних даних, щоб перетворити їх на зручний для автоматизованих розрахунків вид. Причому для кожного типу або модифікації літака ці дані свої. Це значно ускладнює процес автоматизації ІШР, що обумовлено значною за об'ємом та довготривалою за часом задачею додавання характеристик дальності та тривалості польоту для кожного нового типу авіаційної техніки.
Для усунення такого роду труднощів пропонуються методи зменшення спочатку оцифровуваних даних. Наприклад, можна заводити в цифрову базу даних номограми зі збільшеним кроком за параметрами режимів польоту, а при розрахунках використовувати різні процедури згладжування та інтерполяції. Як зазначається в [3], отримані таким способом результати мають відхилення від результатів, отриманих за допомогою номограм, не більше $10 \%$.

Такі підходи, безсумнівно, значно прискорюють процес автоматизації проведення ІШР, дозволяючи для кожного нового типу авіаційної техніки використовувати порівняно невеликий обсяг вихідних даних, що вводиться в системи моделювання. Однак, при цьому, наявність номограм з характеристиками дальності та тривалості польоту літаків продовжує залишатися обов'язковою умовою. Тим не менш, на практиці бувають випадки, коли необхідно виробляти досить детальний IШР (3 варіюванням режимів польоту і корисного навантаження), а номограми характеристик дальності та тривалості відсутні.

За зазначених умов проведеня IШР можливо 3 визначеними припущеннями і з частковою втратою точності результатів. Методика, що викладена в статті, дозволяє проводити розрахунки тактичного радіусу дій літаків з турбореактивною силовою установкою при довільно заданому профілі їх польоту і при різних варіантах корисного навантаження, якщо в якості вихідних даних використовуються не номограми, а тільки загальнодоступні ЛТХ цих літаків. 
Представлені результати розрахунків за представленою методикою дозволяють провести кількісну оцінку отриманих значень тактичних радіусів дій для літаків з турбореактивною силовою установкою (СУ) для різних профілів польоту і різних варіантів корисного навантаження шляхом порівняння 3 контрольними результатами, які отримані на підставі керівництва з льотної експлуатації, зокрема для літака Л-39 [4].

Аналіз останніх досліджень і публікацій. У роботах [1-2] наведені особливості оцифровки номограмм для автоматизації інженерноштурманських розрахунків, та описаний методичний підхід, який дозволяє сформувати та провести верифікації цифрових вихідних даних дальності та тривалості польоту літальних апаратів.

У статті [3] запропоновано методику розрахунку характеристик дальності на підставі набору базових профілів польоту літака встановленого типу. Характеристики досяжності для базових профілів розраховуються за допомогою номограм дальності і тривалості, а для інших профілів, що відрізняються від базових, розрахунок ведеться на підставі спеціально розробленої інтерполяційної методики.

У виданнях [4-7] наведені практична дальність польоту без підвісних паливних баків, практична стеля, об'єм внутрішніх баків, площа крила, розмах крила, маса ЛА без палива та корисного навантаження, максимальна злітна маса, нормальна злітна маса та інші ЛТХ літаків, які використані в якості вихідних даних для розробки методики, що запропонована в даній статті.

У роботах [8-12] наведені формули та порядок обчислення балансу та витрат палива по ділянкам заданого профілю польоту, тривалості набору висоти, кілометрового та погодинного витрат палива, поправочного коефіцієнта, що характеризує зміни температури та щільності повітря за висотами.

Мета статті - розробити методику розрахунку тактичного радіусу дій ЛА на підставі загальнодоступних ЛТХ, без використання вихідних даних 3 розрахунку дальності та тривалості польоту відповідних типів авіаційної техніки.

\section{Виклад основного матеріалу}

Суть методики визначення тактичного радіуса дії ЛА $з$ турбореактивними двигунами на основі загальнодоступних ЛТХ зводиться до наступного. На підставі відомих даних щодо перегінної дальності і наявного запасу палива у внутрішніх паливних баках, розраховується кілометрова витрата палива на встановлених довільно заданих режимах горизонтального польоту на висоті перегінного польоту (висоті практичної стелі).

Для розрахунку значень кілометрових витрат використовуються такі ЛТХ ЛА [4-7]:
- практична (перегінна) дальність польоту без підвісних паливних баків, $L$;

- практична стеля, $H^{n p}$;

- обсяг внутрішніх паливних баків, $v^{n . б \kappa . ~}$

- площа крила, $S^{\kappa p .}$;

- розмах крила, $l^{\kappa p}$;

- максимальна тяга СУ на бесфорсажному режимі роботи на нульовій висоті, $P^{C y_{-} H_{0}}$;

- характеристики скоропідйомності: висота підйому, $H^{n д м}$, та час підйому на вказану висоту, $t^{n \partial \mu}$

- “суха” маса ЛА (маса без палива та корисного навантаження), $m^{\text {cyx. }}$;

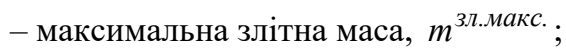

- нормальна злітна маса, $m^{\text {зл.норм. }}$

Далі, використовуючи відомі співвідношення динаміки польоту [8-9], проводиться перерахунок отриманого значення кілометрової витрати палива на перегінній висоті для довільно заданої висоти польоту. При зміні (збільшенні) корисного навантаження і зростанні показника лобового опору (ПЛО) ЛА також здійснюється перерахунок кілометрової витрати палива на заданій висоті польоту з урахуванням зміни (зменшення) величини крейсерської швидкості польоту.

Таким чином при проведенні розрахунків тактичного радіусу ЛА приймаються припущення про те, що:

- на горизонтальних ділянках профілів політ виконується тільки в крейсерському режимі;

- надзвукові режими польоту, режим польоту на максимальну тривалість не враховуються;

- не враховується положення механізації та геометрії крила (для ЛА з крилом змінної геометрії), що не використовуються при здійсненні перегінних перельотів ЛА при крейсерському режимі польоту.

Для розрахунку значення кілометрової витрати палива на перегінній (базовій) висоті польоту використовується схема (рис. 1).

В якості перегінної висоти береться або висота практичної стелі ЛА, або висота, яка найбільш часто використовується при перегоні авіаційної техніки. Якщо практична стеля менша, ніж прийнята висота перегону, то перегінна розрахункова висота береться рівною практичній стелі. Якщо практична стеля більше ніж прийнята висота перегону, то для проведення розрахунків використовується висота перегону. Зазвичай, ця висота становить 8-10 км.

Кілометрова витрата на базовій (перегінній) висоті становить величину

$$
q^{\kappa M}\left(H^{n p}\right)=\frac{m^{\Gamma \Pi}\left(H^{n p}\right)}{L^{\Gamma \Pi}\left(H^{n p}\right)},
$$


де $m^{\Gamma П}\left(H^{n p}\right)$ - маса пального, яка може бути витрачена на горизонтальний політ при здійсненні перегону ЛА;

$$
L^{\Gamma П}\left(H^{n p}\right) \text { - довжина горизонтальної ділянки }
$$

польоту під час здійснення перегону.

Довжина горизонтальної ділянки (1) розраховується як результат віднімання з відомої перегон- ної дальності ЛА довжин ділянок набору та зниження висоти

$$
L^{\Gamma \Pi}\left(H^{n p}\right)=L-L^{\text {наб. }}\left(H^{n p}\right)-L^{3 H}\left(H^{n p}\right),
$$

де $L^{\text {наб. }}\left(H^{n p}\right), L^{3 н}\left(H^{n p}\right)$ - довжини ділянок набору та зниження перегінної висоти, $H^{n p}$.

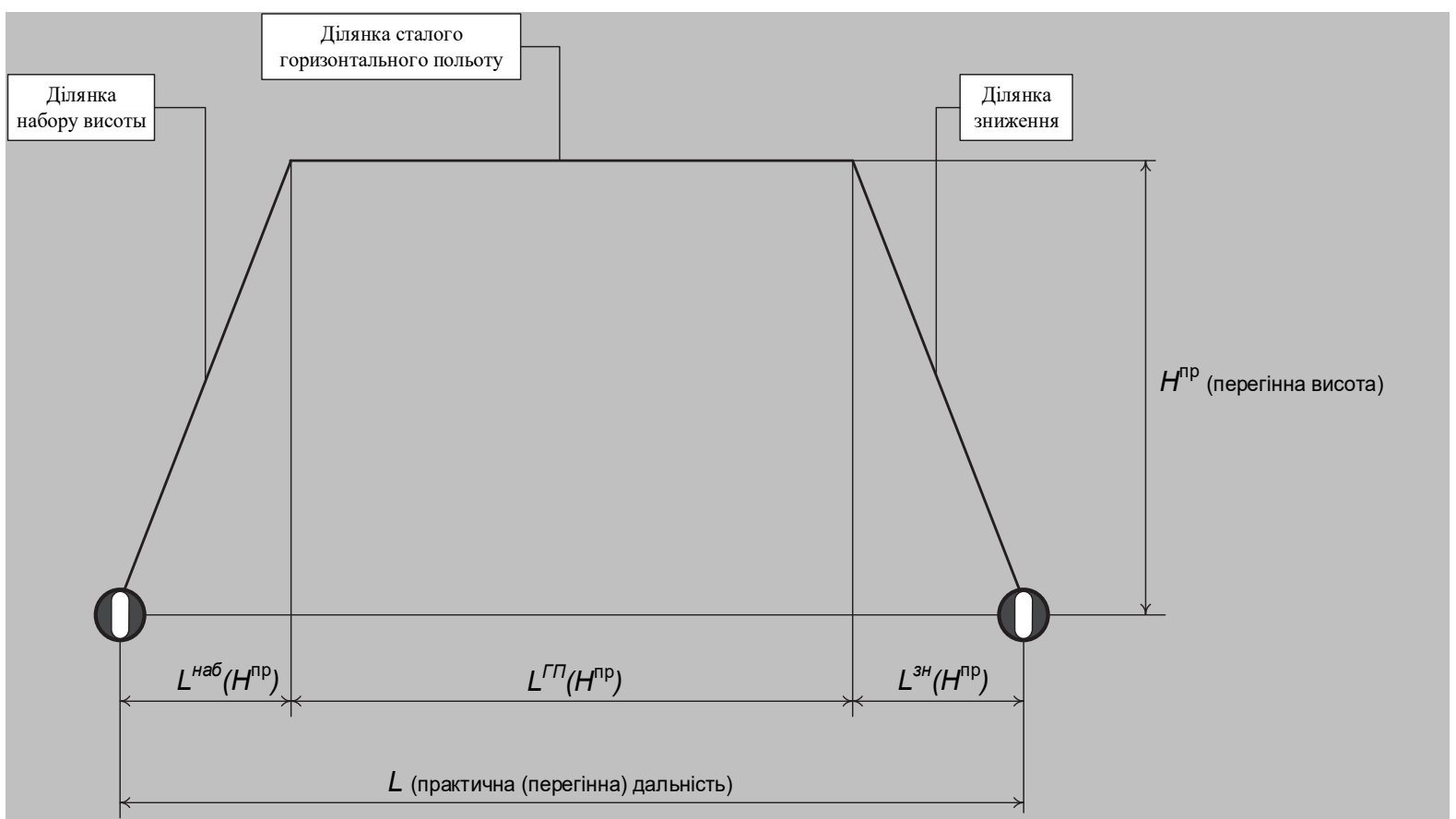

Рис. 1. Розрахункова схема при визначенні кілометрової витрати палива на перегінній (базовій) висоті польоту

Джерело: розроблено авторами за даними [8, С. 278].

Для розрахунку довжини ділянки зниження використовується тригонометричне співвідношення

$$
L^{3 H}\left(H^{n p}\right)=\frac{H^{n p}}{\operatorname{tg} \vartheta^{3 H}},
$$

де $\vartheta^{3 н}$ - кут нахилу траєкторії руху ЛА до поверхні Землі при його зниженні.

Для літаків різних типів цей кут становить величину від 5 до 15 градусів.

Для розрахунку дальності в наборі висоти застосовуються властивості скоропідйомності. Так

$$
\begin{aligned}
& L^{\text {наб. }}\left(H^{n p}\right)=\bar{V}^{\text {наб. }} \cdot t^{\text {наб. }}\left(H^{n p}\right) ; \\
& \bar{V}^{\text {наб. }}=V^{\kappa p} \cdot\left(H^{n p} / 2\right) \cdot \cos \vartheta^{\text {наб. }},
\end{aligned}
$$

де $\bar{V}^{\text {наб. }}$ - середня швидкість польоту літака у наборі висоти;

$V^{\kappa p .}\left(H^{n p} / 2\right)$ - крейсерська швидкість польоту на висоті, що дорівнює половині від висоти, що набирається, $H^{n p}$.

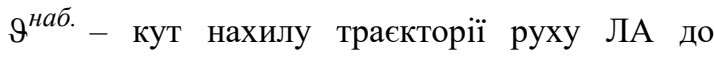
поверхні Землі в наборі висоти. Даний кут, якщо розглядати випадки польотів на граничну дальність, набуває значень від 5 до 30 градусів і більше; $t^{\text {наб. }}\left(H^{n p}\right)$ - час набору висоти $H^{n p}$.

Формули, за якими обчислюється крейсерська швидкість ЛА на заданій висоті польоту, наведені нижче.

Оскільки набір висоти в залежності від часу здійснюється не рівномірно, а по барограмі набору висоти [8], то тривалість набору висоти слід рахувати за формулою

$$
t^{\text {наб. }}\left(H^{n p}\right)=\alpha \cdot H^{n p \beta},
$$

де $\alpha$ - постійний коефіцієнт, який обчислюється в залежності від відомих характеристик швидкопідйомності ЛА: $\alpha=t^{n д м} / H^{n д м \beta}$. За відсутності ЛТХ щодо скоропідйомності, приймається $\alpha=1 / 300 x_{8} / \kappa м^{\beta}$;

$\beta$ - постійний показник ступеня, його значення приймається рівним 3.

У формулі (6) значення заданої висоти обчислюється у кілометрах, а тривалість часу набору висоти - у хвилинах.

Запас палива, що витрачається на горизонтальний політ, у формулі (1), розраховується як результат віднімання з повного запасу палива маси палива, 
що витрачається в наборі та зниженні висоти, а також відводиться в нормативні резерви і залишок, що не виробляється.

$$
\begin{aligned}
& m^{\Gamma \Pi}\left(H^{n p}\right)=m^{n}-m^{\text {наб. }}\left(H^{n p}\right)- \\
& -m^{\text {зн }}\left(H^{n p}\right)-m^{\text {нвг }}-m^{\text {зем. }}-m^{\text {зал.н.' }}
\end{aligned}
$$

де $m^{n}$ - маса палива при повній заправці внутрішнішніх паливних баків літака;

$$
m^{\text {наб. }}\left(H^{n p}\right), m^{3 н}\left(H^{n p}\right) \text { - витрата палива на на- }
$$

бір та зниження висоти $H^{n p}$;

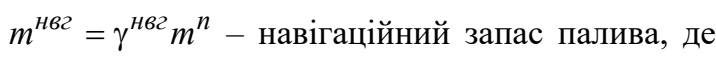

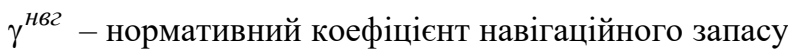
(до 5\%);

$m^{\text {зем. }}=\gamma^{\text {зем }} m^{n}-$ витрата палива на виконання випробування двигуна та керування літаком по аеродромі перед зльотом та після посадки, де $\gamma^{\text {зем }}$ нормативний коефіцієнт витрати палива на землі (приблизно 2\%);

$m^{\text {зал.н. }}=\gamma^{\text {зал.н. }} m^{n}-$ залишок палива, що не виробляється, де $\gamma^{\text {зал.н. }}$ - коефіцієнт залишку, що не виробляється (1\%).

3 урахуванням введених норм за резервами та залишками палива (7) може бути записано як

$$
\begin{gathered}
m^{\text {ПП }}\left(H^{n p}\right)=0,92 m^{n}-m^{\text {наб. }}\left(H^{n p}\right)-m^{3 н}\left(H^{n p}\right)= \\
=0,92 v^{n . б \kappa} \cdot \rho^{n}-m^{\text {наб. }}\left(H^{n p}\right)-m^{3 \mu}\left(H^{n p}\right),
\end{gathered}
$$

де $v^{n . б к .}$ - обсяг внутрішніх паливних баків ЛА;

$\rho^{n}-$ густина авіаційного гасу.

Кількість палива, що витрачається на набір перегінної висоти, розраховується пропорційно відношенню дальності в наборі висоти до перегінної дальності

$$
m^{\text {наб. }}\left(H^{n p}\right)=\mu^{\text {наб. }} \frac{L^{\text {наб. }}\left(H^{n p}\right)}{L} \cdot 0,92 m^{n},
$$

де $\mu^{\text {наб. }}=1,1 \div 2,0$ - коефіцієнт перевищення кілометрової витрати палива в наборі висоти над кілометровою витратою палива на ділянці горизонтального польоту. Даний коефіцієнт обумовлений збільшеною годинною витратою палива при роботі СУ в режимі зльоту, меншою швидкістю польоту в порівнянні з ділянкою горизонтального польоту.

Кількість палива, що витрачається на зниження 3 перегінної висоти, розраховується за аналогічним співвідношенням

$$
m^{3 H}\left(H^{n p}\right)=\mu^{3 H} \frac{L^{3 H}\left(H^{n p}\right)}{L} \cdot 0,92 m^{n},
$$

де $\mu^{\text {зн }}=0,1 \div 0,3$ - коефіцієнт зменшення кілометрової витрати палива на зниженні висоти порівняно 3 ділянкою горизонтального польоту Зменшення витрати палива відбувається за рахунок значного дроселювання двигуна на режимі зниження. При цьому суттєво зменшується годинна витрата палива за збереження або збільшення швидкості польоту.

Кілометрова витрата палива на перегінній висоті, розрахована за допомогою (1) - (10), може бути перерахована для довільної висоти польоту за умови, якщо політ виконується в режимі крейсерської швидкості польоту. Для цього слід скористатися наступним співвідношенням, що зв'язує кілометрову та годинну витрати палива [10]:

$$
3,6 \cdot q^{\kappa м}\left(H^{n p}\right) \cdot V^{\kappa p}\left(H^{n p}\right)=C^{2}\left(H^{n p}\right),
$$

де - кілометрова витрата палива при польоті на крейсерському режимі на перегінній висоті;

$$
C^{2}\left(H^{n p}\right) \text { - годинна витрата палива на тому ж }
$$
режимі (перегінна висота, крейсерська швидкість).

Величина годинної витрати палива при зміні швидкості польоту ЛА та висоти польоту змінюється у значних межах (рис. 2) [8].

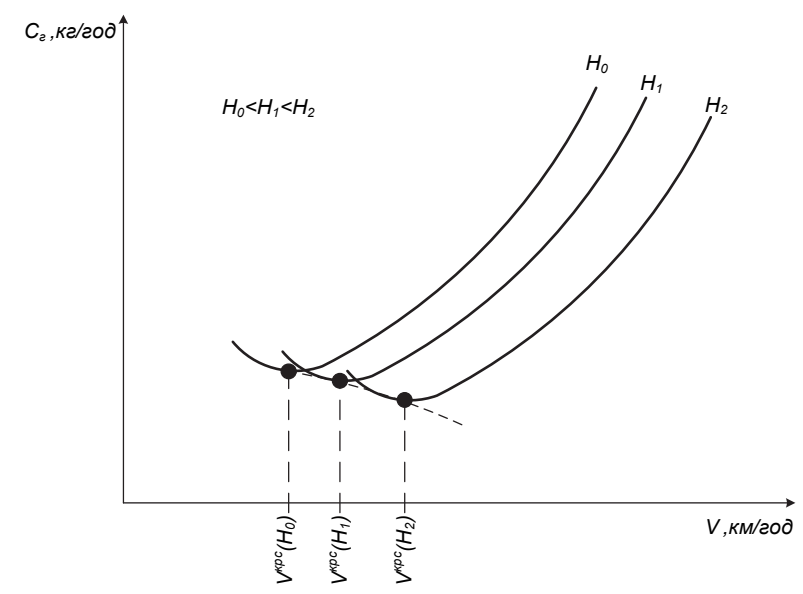

Рис. 2. Зміна годинної витрати палива в залежності від режиму польоту (дозвукового)

Джерело: [8, С. 96].

Однак, якщо політ виконується на крейсерській швидкості, то годинна витрата змінюватиметься незначно (пунктирна лінія на рис. 2). Така зміна може бути врахована за допомогою поправочного коефіцієнту, що характеризує зміну температури та щільності повітря за висотою [8]:

$$
C^{2}(H)=\sqrt{\frac{\rho_{H}}{\rho_{0}} \frac{T_{0}}{T_{H}}} C_{0}^{2},
$$

де $C^{2}(H)$ - годинна витрата для крейсерського режиму на довільно заданій висоті;

$C_{0}^{2}$ - годинна витрата для крейсерського режиму на нульовій висоті;

$\rho_{0}, \rho_{H}-$ щільність повітря на нульовій висоті та висоті перерахунку;

$T_{0}, T_{H}-$ температура повітря на нульовій висоті та висоті перерахунку. 
На підставі (11) і (12) можна записати

$$
q^{\kappa M}(H)=\frac{C^{2}(H)}{3,6 \cdot V^{\kappa p}(H)}=\frac{\sqrt{\frac{\rho_{H}}{\rho_{0}} \frac{T_{0}}{T_{H}}} C_{0}^{2}}{3,6 \cdot V^{\kappa p}(H)},
$$

де $V^{\kappa p}(H)$ - крейсерська швидкість польоту на висоті перерахунку, $H$.

Невідома крейсерська швидкість ЛА на заданій висоті визначається за умови рівності створюваної підйомної сили та сили ваги ЛА:

$$
V^{\kappa p}(H)=\sqrt{\frac{2 G^{\text {пол. }}}{C_{y}^{\kappa p} S \rho_{H}}},
$$

де $G^{\text {пол. }}$ - польотна вага літака;

$$
C_{y}^{\kappa p} \text { - коефіцієнт підйомної сили на режимі }
$$

польоту з крейсерською швидкістю на висоті перерахунку;

$S$ - площа крила літака;

$\rho_{H}$ - щільність повітря на висоті перерахунку.

Коефіцієнт підйомної сили для крейсерською швидкістю польоту (згідно з [8]):

$$
C_{y}^{\kappa p}=\sqrt{\frac{C_{x_{0}} \pi \lambda_{e \phi .}}{3}}
$$

де $C_{x_{0}}$-коефіцієнт сили аеродинамічного опору літака при нульовому куті атаки (з нульовою підйомною силою);

$$
\lambda_{\text {э } \phi .}=(0,7 \div 0,95) \lambda=(0,7 \div 0,95) \cdot l^{\kappa p .2} / S^{\kappa p .}-
$$

ефективне подовження крила літака.

Ця величина становить певну частку відомого геометричного подовження крила. Для визначення значення нульового коефіцієнта сили аеродинамічного опору, використовується співвідношення рівності наявної реактивної тяги силової установки літака на висоті практичної стелі і сили аеродинамічного опору при сталому горизонтальному польоті на цій же висоті з крейсерською швидкістю польоту. Відомо, що для практичної стелі величина крейсерської швидкості практично дорівнює максимальній швидкості польоту за можливостей силової установки. Тобто

$$
\begin{gathered}
C_{x} \frac{\rho_{H^{n p}} \cdot V^{\kappa p}\left(H^{n p}\right)^{2}}{2} S=P^{C y_{-} H^{n p}}= \\
=P^{C y_{-} H_{0}} \frac{\rho_{H^{n p}}}{\rho_{0}} \frac{T_{0}}{T_{H^{n p}}},
\end{gathered}
$$

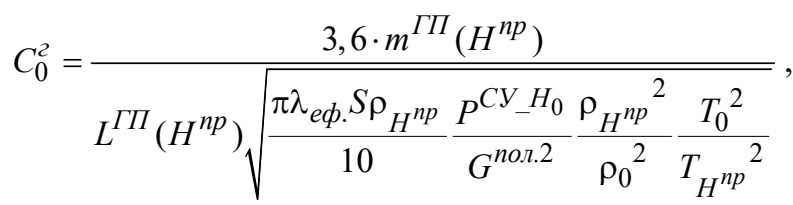

де $C_{x}=C_{x_{0}}+C_{y}^{2} / \pi \lambda_{e \phi}-$ коефіцієнт повного аеродинамічного опору, з урахуванням індуктивного опору, що виникає при ненульовій підйомній силі.

3 урахуванням того, що коефіцієнт підйомної сили тут дорівнює коефіцієнту на крейсерській швидкості польоту (15), коефіцієнт опору набуде вигляду $C_{x}=5 / 3 \cdot C_{x_{0}}$;

$$
P^{C y_{-} H^{n p}}=P^{C y_{-} H_{0}} \frac{\rho_{H^{n p}}}{\rho_{0}} \frac{T_{0}}{T_{H^{n p}}}-\text { максимальна }
$$

реактивна тяга СУ на висоті практичної стелі на безфорсажному режимі iї роботи. Величина тяги змінюється із збільшенням висоти польоту;

$$
P^{C y_{-} H_{0}} \text { - наявна реактивна тяга силової уста- }
$$
новки на нульовій висоті;

$\rho_{H^{n p}}, T_{H^{n p}}$ - щільність та температура повітря на висоті практичної стелі;

$\rho_{0}, T_{0}$ - щільність та температура повітря на нульовій висоті.

3 урахуванням (14) співвідношення (16) набуде вигляду

$$
\frac{5}{3} C_{x_{0}} \frac{G^{\text {пол. }}}{\sqrt{\frac{C_{x_{0}} \pi \lambda_{e \phi}}{3}}}=P^{C y_{-} H_{0}} \frac{\rho_{H^{n p}}}{\rho_{0}} \frac{T_{0}}{T_{H^{n p}}} .
$$

Звідки

$$
C_{x_{0}}=\frac{3 \pi \lambda_{e \phi}}{25}\left(\frac{P^{C y_{-} H_{0}}}{G^{\text {пол. }}} \frac{\rho_{H^{n p}}}{\rho_{0}} \frac{T_{0}}{T_{H^{n p}}}\right)^{2} .
$$

Підставивши (18) в (14), отримаємо вираз для розрахунку значень крейсерської швидкості польоту в залежності від встановленої висоти горизонтального польоту літака

$$
V^{\kappa p}(H)=\sqrt{\frac{2 G^{\text {пол. }}}{\frac{\pi \lambda_{\text {ер. }}}{5} \frac{P^{C У_{-} H_{0}}}{G^{\text {пол. }}} \frac{\rho_{H^{n p}}}{\rho_{0}} \frac{T_{0}}{T_{H^{n p}}} S \rho_{H}}}
$$

Тоді вираз (13) прийме вигляд

$$
=\frac{C_{0}^{2}}{3,6} \sqrt{\frac{\pi \lambda_{e \phi .} S \rho_{H}}{10} \frac{P^{C y_{-} H_{0}}}{G^{\text {пол. } 2} \frac{\rho_{H^{n p}} \rho_{H}}{\rho_{0}{ }^{2}} \frac{T_{0}{ }^{2}}{T_{H^{n p}} T_{H}}} .}
$$

Годинна витрата палива на нульовій висоті при крейсерській швидкості польоту (21) визначається 3 формули (20), записаної для перегінної висоти 3 відомим значення кілометрової витрати палива.

чається на ділянці горизонтального польоту і довжина цієї ділянки при здійсненні перегінного польо- 
ту ЛА на встановленій висоті перегону.

Дані величини розраховуються згідно 3 (2) - висоті практичної стелі, а на встановленій перегінній висоті, то вираз (21) слід записувати як

(10). У разі, якщо перегін ЛА здійснюється не на

$$
C_{0}^{2}=\frac{3,6 \cdot m^{\Gamma \Pi}\left(H^{n p}\right)}{L^{\Gamma \Pi}\left(H^{n p}\right) \sqrt{\frac{\pi \lambda_{e \phi .} S \rho_{H^{n p}}}{10} \frac{P^{C y_{-} H_{0}}}{G^{n о л .2}} \frac{\rho_{H^{n p}} \rho_{\hat{H}^{n p}}}{\rho_{0}^{2}} \frac{T_{0}^{2}}{T_{H^{n p}} T_{H^{n p}}}}},
$$

де $H^{n p}$ - висота практичної стелі ЛА;

$\hat{H}^{n p}$ - встановлена перегінна висота, $\hat{H}^{n p}<H^{n p}$.
3 урахуванням (20) і (22) формула для перерахунку кілометрової витрати при крейсерському режимі польоту для довільно встановленої висоти набуде наступного вигляду

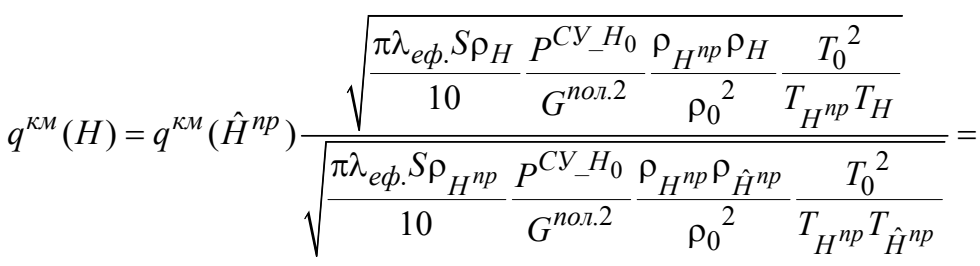

$$
\begin{aligned}
& =q^{\kappa M}\left(\hat{H}^{n p}\right) \sqrt{\frac{\rho_{H}{ }^{2}}{\rho_{H^{n p}} \rho_{\hat{H}^{n p}}} \frac{T_{\hat{H}^{n p}}}{T_{H}}} \text {. }
\end{aligned}
$$

Для врахування зміни варіанта корисного навантаження ЛА слід навести наступний порядок міркувань. При зміні варіанта корисного навантаження відбувається збільшення коефіцієнта аеродинамічного опору ЛА при нульовому куті атаки (за рахунок підвіски зовнішніх пристроїв), а також польотної маси літака (за рахунок додавання власне корисного навантаження). Під час проведення IШР збільшення аеро-динамічного опору за рахунок зовнішньої підвіски оцінюється за допомогою показника лобового опору (ПЛО). Новий коефіцієнт $\hat{C}_{x_{0}}$ розраховується на підставі наступної пропорції

$$
\hat{C}_{x_{0}}=\frac{\Pi Л O}{\Pi Л O_{0}} C_{x_{0}}
$$

де $\hat{C}_{x_{0}}, C_{x_{0}}$ - коефіцієнти аеродинамічного опору літака при нульовому куті атаки з новим та старим показниками лобового опору;

ПЛО, ПЛО 0 - показники лобового опору літака із зовнішньою підвіскою і без підвіски, відповідно.

Тоді, з урахуванням (17):

$$
\hat{C}_{x_{0}}=\frac{3 \pi \lambda_{\text {ep }}}{25} \frac{\text { ПЛО }}{\text { ПЛО }}\left(\frac{P^{C У_{-} H_{0}}}{G^{\text {пол. }}} \frac{\rho_{H^{n p}}}{\rho_{0}} \frac{T_{0}}{T_{H^{n p}}}\right)^{2} \text {. }
$$

Звідки вираз (19) для розрахунку крейсерської швидкості польоту на встановленій висоті набуде вигляду

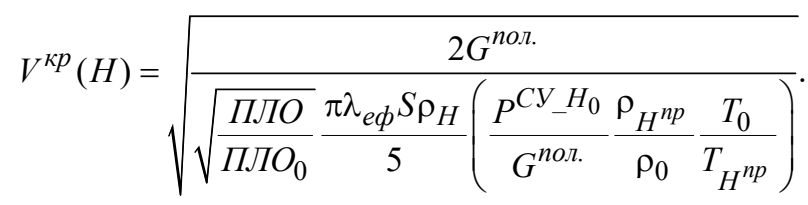

Для перерахунку кілометрової витрати при збільшенні ПЛО за рахунок корисного навантаження слід використовувати відношення наступного виду

$$
\begin{gathered}
\frac{q^{\kappa м}(H, \text { ПлО })}{q^{\kappa M}(H, \Pi Л O)}= \\
=\frac{C^{2}\left(H, \Pi Л O_{0}\right) \cdot 3,6 V^{\kappa p}(H, \Pi Л O)}{3,6 V^{\kappa p}\left(H, \Pi Л O_{0}\right) \cdot C^{2}(H, \Pi Л O)}=k(\text { ПЛО }),
\end{gathered}
$$

де $q^{\kappa м}\left(H, П Л O_{0}\right), q^{\kappa м}(H, П Л O)-$ кілометрові витрати палива для літака без корисного навантаження та $з$ корисним навантаженням;

$$
C^{2}\left(H, \Pi л O_{0}\right), C^{2}(H, \Pi л O), V^{\kappa p}\left(H, \Pi л O_{0}\right),
$$

$V^{\kappa p}(H, П Л O)$ - годинні витрати пального та крейсерські швидкості польоту для літака без корисного навантаження та 3 корисним навантаженням.

Тоді перерахунок здійснюватиметься за формулою

$$
q^{\kappa м}(H, \Pi Л О)=\frac{q^{\kappa м}\left(H, \Pi Л O_{0}\right)}{k(П Л О)} .
$$

Приймаючи, що $C^{2}\left(H, \Pi л O_{0}\right) \approx C^{2}(H, \Pi Л O)$, в силу того, що $C^{2}\left(H, \Pi Л O_{0}\right) \in$ екстремум (політ виконується з крейсерською швидкістю, що обумов- 
лює мінімальну годинну витрату палива) і порівняно невеликі зміни аргументу функції в області іiї екстремуму не призводять до помітної іiі зміни, коефіцієнт перерахунку прийме вираз

$$
\begin{aligned}
k(\text { ПЛО }) & \approx \frac{V^{\kappa p}(H, \text { ПЛО })}{V^{\kappa p}(\text { П ПлО })}= \\
& =\sqrt{\frac{1+\gamma^{\text {нав. }}}{\sqrt{\frac{\Pi Л O}{\Pi л O_{0}}}}},
\end{aligned}
$$

де $G_{0}^{\text {nол. }}, G^{\text {нав. }}$ - політна вага ЛА без урахування корисного навантаження і вага корисного навантаження, відповідно;

$\gamma^{\text {нав. }}=G^{\text {нав. }} / G_{0}^{\text {пол. }}-$ коефіцієнт, що характеризує відношення ваги корисного навантаження до польотної ваги ЛА.

Звідси перерахунок значень кілометрової витрати при зростанні показника лобового опору літака за рахунок корисного навантаження буде здійснюватися за такою формулою

$$
q^{\kappa м}(H, \Pi Л O)=\frac{q^{\kappa м}\left(H, \Pi Л O_{0}\right)}{\sqrt{1+\gamma^{\text {нaв. }}}} \sqrt[4]{\frac{\Pi Л O}{\Pi Л O_{0}}},
$$

де $q^{\kappa м}\left(H, П Л O_{0}\right)$ - кілометрова витрата палива для літака без корисного навантаження (23);

ПЛО, ПЛО 0 - показники лобового опору літака без корисного навантаження та $з$ навантаженням.

Для визначення характеристик точності розробленої методики були зроблені порівняльні розрахунки. Порівнювалися результати з розрахунку тактичних радіусів дії ЛА, отримані за допомогою запропонованої методики розрахунку і методики на основі повномірних даних (номограм характеристик дальності і тривалості польоту).

Тактичні радіуси дій ЛА розраховувалися для заданих профілів, режимів польоту та варіантів корисного навантаження літаків. Розрахунковий профіль польоту формувався у вигляді сукупності ділянок горизонтального польоту (ГП) на встановлених висотах, ділянок набору та зниження висоти при зльоті, посадці та переході з однієї ділянки ГП на наступну. Ділянки ГП складалися з ділянок невизначеної та заданої довжини. У кожну сторону польоту (до рубежу і від рубежу досяжності) встановлювалося по одній ділянці невизначеної довжини і будьяка кількість ділянок заданої довжини.

Ділянки ГП заданої довжини, зниження та набору висоти нумерувалися з використанням подвійного індексу $i, j$, де $i=1,2$ - індекс, що позначає напрямок польоту ( $i=1$ - напрямок до рубежу досяжності, $i=2$ - від рубежу досяжності); $j=1,2, \ldots, m(n)$ - нумерація ділянок певної довжини (ГП, зниження або набору висоти) у пряму або зво- ротну сторону польоту; $m(n)$-кількість ділянок певної довжини при польоті до рубежу (від рубежу) досяжності.

Формула для обчислення величини тактичного радіусу дії ЛА може бути отримана з рівняння балансу відстаней і витрат палива по ділянках заданого профілю польоту в пряму і зворотну сторону [10]. Ця формула має вигляд

$$
\begin{gathered}
R^{m}=\frac{0,92 m^{n}-\sum_{i=1}^{2} \sum_{j=1}^{m(n)} m_{i, j}^{n . д i л .}}{q_{1}^{\kappa M}+q_{2}^{\kappa M}}+ \\
+\frac{\sum_{i=1}^{2} q_{i}^{\kappa M} \sum_{j=1}^{m(n)} L_{i, j}}{q_{1}^{\kappa M}+q_{2}^{\kappa M}}+\frac{(-1)^{\delta+1} L_{3 л-n o c .} q_{\delta}^{\kappa M}}{q_{1}^{\kappa M}+q_{2}^{\kappa M}},
\end{gathered}
$$

де $m^{n}=v^{n . б \kappa} \rho^{n}-$ наявний запас палива у внутрішніх паливних баках;

$$
m_{i, j}^{n . д i л .}, i=1,2 ; j=1,2, \ldots, m(n)-\text { витрати па- }
$$

лива на подолання ділянок певної довжини (ГП, набору та зниження висоти, барражування в зоні чергування);

$m(n)$ - кількість ділянок певної довжини при польоті в пряму та зворотні сторони;

$q_{1}^{\kappa м}, q_{2}^{\kappa M}$ - кілометрові витрати палива, розраховані для ділянок ГП невизначеної довжини при польоті в пряму та зворотну сторони, відповідно;

$$
L_{i, j}, i=1,2 ; j=1,2, \ldots, m(n) \text { - довжини діля- }
$$

нок певної довжини (ГП, набору та зниження висоти, баражування в зоні) при польоті до рубежу і від рубежу досяжності, відповідно. Довжина ділянки барражування у зоні чергування має нульове значення;

$L_{\text {зл-пос. }}$ - відстань між аеродромами зльоту та посадки.

У разі, якщо посадка здійснюється на аеродром, який по відношенню до рубежу досяжності $є$ тиловим, то додаток, в якому міститься цей параметр, входить у (31) зі знаком мінус і множиться на кілометрову витрату для ділянки ГП невизначеної довжини під час польоту до рубежу. У випадку, якщо посадка проводиться на передовий аеродром, тоді - зі знаком плюс і множиться на кілометрову витрату палива при польоті від рубежу;

$\delta=1,2$ - ознака розташування аеродрому посадки. Якщо аеродром є тиловим, то $\delta=1$, якщо передовим - то $\delta=2$.

Порівняльні розрахунки проводилися для декількох варіантів встановленого профілю польоту, схема ділянок якого наведена на рис. 3 . 


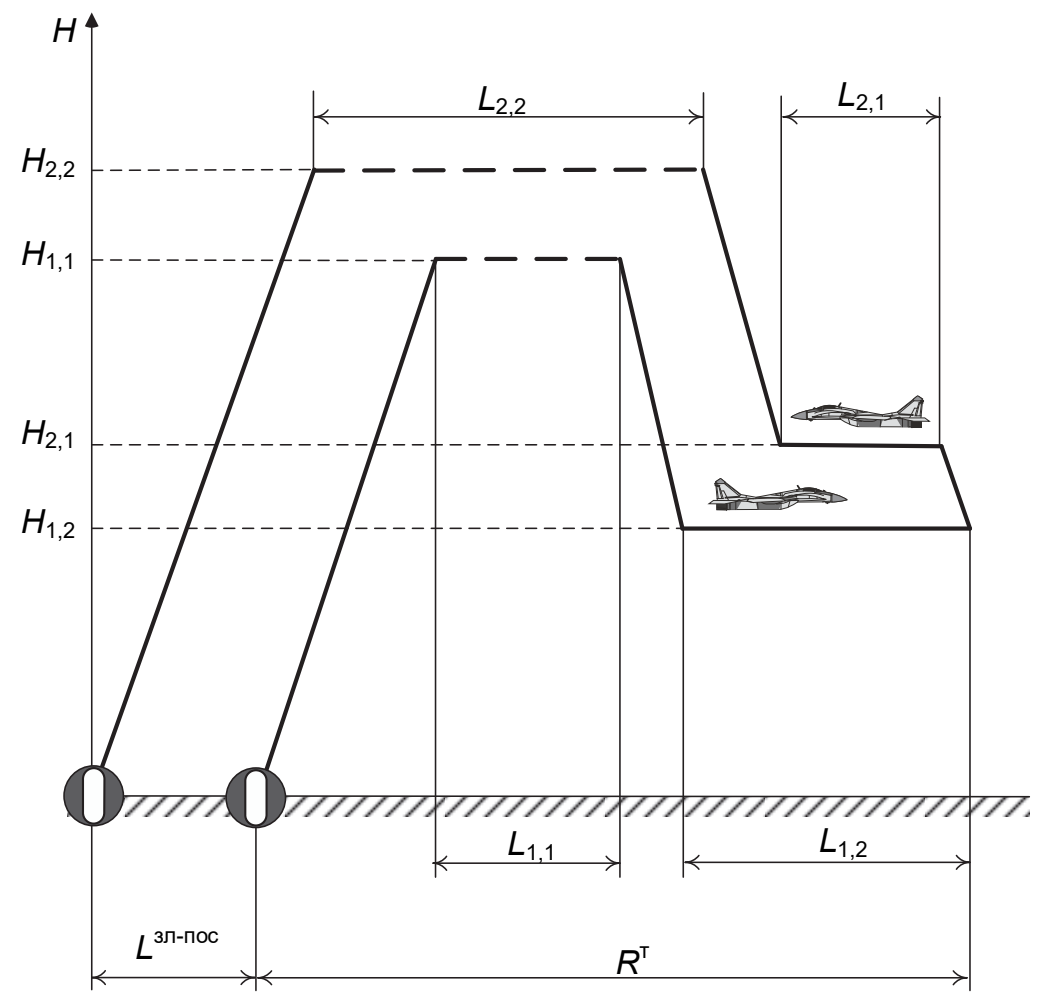

Рис. 3. Схема ділянок встановленого профілю польоту Джерело: розроблено авторами за даними [9, С. 108].

Вихідні дані щодо варіантів встановленого профілю польоту наведені в табл. 1.

Вихідні дані по ЛТХ розглянутих типів літаків наведені в табл. 2 і 3.
Розраховані значення тактичних радіусів дій ЛА в залежності від варіантів їх корисного навантаження і варіантів профілю польоту наведені в табл. 4.

Таблиця 1

Варіанти встановленого профілю польотів

\begin{tabular}{|c|c|c|c|c|c|}
\hline $\begin{array}{c}\text { Найменування } \\
\text { варіантів }\end{array}$ & $\begin{array}{c}H_{1,1} / L_{1,1}, \\
{[\mathrm{M}] /[\mathrm{\kappa м}]}\end{array}$ & $\begin{array}{c}H_{1,2} / L_{1,2}, \\
{[\mathrm{M}] /[\mathrm{\kappa м}]}\end{array}$ & $\begin{array}{c}H_{2,1} / L_{2,1}, \\
{[\mathrm{M}] /[\mathrm{\kappa м}]}\end{array}$ & $\begin{array}{c}H_{2,2} / L_{2,2}, \\
{[\mathrm{M}] /[\mathrm{\kappa м}]}\end{array}$ & $\begin{array}{c}L_{3 л-n о с}, \\
{[\mathrm{\kappa м}]}\end{array}$ \\
\hline Варіант 1 & $\begin{array}{c}3000 / \text { невизна- } \\
\text { чена довжина }\end{array}$ & $100 / 40$ & $100 / 40$ & $\begin{array}{c}7000 / \text { невизна- } \\
\text { чена довжина }\end{array}$ & 0 \\
\hline Варіант 2 & $\begin{array}{c}5000 / \text { невизна- } \\
\text { чена довжина }\end{array}$ & $100 / 40$ & $100 / 40$ & $\begin{array}{c}7000 / \text { невизна- } \\
\text { чена довжина }\end{array}$ & 0 \\
\hline
\end{tabular}

Джерело: розроблено авторами.

Таблиця 2

Льотно-техничні характеристики типів ЛА, що розглядаються

\begin{tabular}{|c|c|c|c|c|c|}
\hline Тип ЛА & $\begin{array}{c}\text { Практична } \\
\text { стеля / } \\
\text { Перегінна } \\
\text { висота, } \\
{[\text { Км]/[км] }}\end{array}$ & $\begin{array}{c}\text { Перегінна } \\
\text { дальність, } \\
{[\text { км] }}\end{array}$ & $\begin{array}{c}\text { Об'єм паливних } \\
\text { баків, } \\
{[\text { [л] }}\end{array}$ & $\begin{array}{c}\text { Суха” маса, } \\
\text { [кг] }\end{array}$ & $\begin{array}{c}\text { Максимальна } \\
\text { злітна маса, } \\
\text { [кг] }\end{array}$ \\
\hline Су-25 & $10 / 10$ & 1950 & 3660 & 9315 & 17600 \\
\hline Су-24М & $11 / 10$ & 2775 & 13000 & 21200 & 39700 \\
\hline МиГ-29 & $18 / 10$ & 1430 & 4200 & 10900 & 18480 \\
\hline Л-39 & $11,5 / 10$ & 1015 & 1300 & 3395 & 4700 \\
\hline
\end{tabular}

Джерело: розроблено авторами за даними [4-7]. 
Льотно-технічні характеристики типів ЛА, що розглядаються

\begin{tabular}{|c|c|c|c|c|c|}
\hline \multirow[b]{2}{*}{ Тип ЛА } & \multirow[b]{2}{*}{$\begin{array}{c}\text { Площа крила, } \\
{\left[\mathrm{M}^{2}\right]}\end{array}$} & \multirow[b]{2}{*}{$\begin{array}{c}\text { Розмах крила, } \\
\text { [м] }\end{array}$} & \multirow{2}{*}{$\begin{array}{c}\text { Тяга СУ } \\
\text { на землі } \\
\text { (максимал.), } \\
{[\mathrm{H}]}\end{array}$} & \multicolumn{2}{|c|}{ Швидкопідйомність } \\
\hline & & & & $\begin{array}{c}\text { Висота, } \\
{[\mathrm{M}]}\end{array}$ & $\begin{array}{c}\text { Час, } \\
\text { [хвил.] }\end{array}$ \\
\hline Cy-25 & 30,1 & 14,36 & $2 \times 41000$ & 4000 & 1 \\
\hline Cy-24M & 55,0 & 17,0 & $2 \times 78800$ & 5000 & 1 \\
\hline МиГ-29 & 38,06 & 11,36 & $2 \times 50400$ & 12000 & 1 \\
\hline Л-39 & 18,8 & 9,46 & 16870 & 10000 & 16,9 \\
\hline
\end{tabular}

Джерело: розроблено авторами за даними [4-7].

Таблиця 4

Варіанти корисної навантаження та тактичні радіуси ЛА за варіантами профілю польоту

\begin{tabular}{|c|c|c|c|c|}
\hline Тип ЛА & ПЛ $C_{0} /$ ПЛС & $\begin{array}{c}m_{\text {нав. }}, \\
{[\text { Кг] }}\end{array}$ & Варіант профілю & $\begin{array}{c}\text { Тактичний радіус, } \\
\text { [км] }\end{array}$ \\
\hline \multirow{3}{*}{ Cy-25 } & $120 / 160$ & 4000 & Варіант 1 & 528 \\
\hline & $120 / 200$ & 8000 & Варіант 1 & 531 \\
\hline & $120 / 160$ & 4000 & Варіант 2 & 588 \\
\hline \multirow{3}{*}{ Сy-24M } & $160 / 220$ & 6000 & Варіант 1 & 665 \\
\hline & $160 / 260$ & 8000 & Варіант 1 & 651 \\
\hline & $160 / 220$ & 6000 & Bapiaнт 2 & 745 \\
\hline \multirow{3}{*}{ МиГ-29 } & $120 / 140$ & 1000 & Варіант 1 & 201 \\
\hline & $120 / 160$ & 2000 & Варіант 1 & 199 \\
\hline & $120 / 140$ & 1000 & Bapiaнт 2 & 227 \\
\hline \multirow{3}{*}{ Л-39 } & $80 / 80$ & 0 & Варіант 1 & $255(315)$ \\
\hline & $80 / 100$ & 120 & Варант 1 & 243 \\
\hline & $80 / 80$ & 0 & Варіант 2 & $281(330)$ \\
\hline
\end{tabular}

Джерело: розроблено авторами.

Для літака Л-39, у графі “Тактичний радіус" в дужках наведено значення радіусу, який отриманий 3 використанням керівництва, що містить методику та вихідні дані для розрахунку дальності та тривалості польоту [4]. Тактичний радіус дії, розрахований $з$ використанням керівництва, на $15 \div 20 \%$ більший у порівнянні з результатами розрахунків за запропонованою у статті методикою.

\section{Висновки}

В статті запропоновано методику розрахунку тактичного радіусу дій ЛА на основі загальнодоступних ЛТХ, без використання вихідних даних 3 розрахунку дальності та тривалості польоту відповідних типів авіаційної техніки.

Методика дозволяє розраховувати кілометрові витрати палива і тактичні радіуси літаків з турбореактивною силовою установкою з урахуванням зміни їх режиму польоту по висоті, а також при зміні корисного навантаження.
Методика забезпечує збіг з результатами розрахунку характеристик дальності, одержуваних на основі посібників 3 розрахунку дальності та тривалості польоту ЛА відповідних типів, до $15 \div 20 \%$.

Обмеженнями щодо використання запропонованої методики є:

- урахування лише крейсерських дозвукових режимів польоту;

- неможливість врахування зміни геометрії крила та інших льотно-технічних особливостей ЛА.

Розроблену методику доцільно використовувати при розробці спеціального програмного забезпечення для систем моделювання бойових дій авіації в яких предбачено вирішення завдань, що не потребють підвищених вимог до точності отриманих результатів.

\section{Список літератури}

1. Моисеев В. Н. Особенности оцифровки номограмм для автоматизации инженерно-штурманских расчётов. Перспективы развития информачионных технологий. 2016. № 38. С. 20-26.

2. Смик С. І., Кудрявцев А. Ф., Клюшніков І. М., Кулініч І. А. Методичний підхід до формування та верифікації цифрових вихідних даних дальності та тривалості польоту літальних апаратів. Збірник наукових праць Харківського на- 
ичіонального університету Повітряних Сил. 2019. № 4(62). С. 85-90. https://doi.org/10.30748/zhups.2019.62.12.

3. Моисеев В. Н. Методика расчёта рубежей досягаемости летательных аппаратов на основе сведений о тактических радиусах. Автоматизация процессов управления. 2017. № 1(47). С. 10-15.

4. Самолёт Л-39. Руководство по лётной эксплуатации. Москва : “Военное издательство”, 1988. 227 с.

5. Harry B. Indian Naval Aviation. Part 1 : web site. URL: http:// www.acig.org (accessed 30.11.2021)

6. Раєвський Г. К., Смик С. І. Дальність та тривалість польоту. Практична аеродинаміка літаків Су-24 : навч. метод. посіб. Харків : ХІ ВПС, 2003. $31 \mathrm{c}$.

7. Техника пилотирования и самолетовождение самолета МиГ-29 : метод. пособ. под. ред. Н. Н. Котова. Москва : “Военное издательство”, 1989. 369 с.

8. Динамика полёта. Под ред. А. М. Мхитаряна. Москва : “Машиностроение”, 1971. 368 с.

9. Баженов С. Г. Основы динамики полета. Москва : ЦАГИ, 2021. 237 с.

10. Воздушная навигация. Б. А. Таранов и др. Москва : "Военное издательство”, 1990. 463 с.

11. Байдаков В. Б., Клумов А. С. Аэродинамика и динамика полета летательных аппаратов : учеб. пособ. Москва : Машиностроение, 1979. 344 с.

12. Никифоров О. В. Тенденції розвитку авіації Збройних Сил України. Збірник наукових пращь Харківського нащіонального університету Повітряних Сил. 2017. № 5(54). С. 23-28.

\section{Відомості про авторів:}

\section{Никифоров Олексій Віленович}

кандидат технічних наук старший науковий співробітник провідний науковий співробітник

Харківського національного університету

Повітряних Сил ім. І. Кожедуба,

Харків, Україна

https://orcid.org/0000-0002-0207-5175

\section{Смик Сергій Іванович}

кандидат технічних наук

старший науковий співробітник

Харківського національного університету

Повітряних Сил ім. І. Кожедуба,

Харків, Україна

https://orcid.org/0000-0001-8941-2631

\section{Мартиненко Павло Миколайович}

старший науковий співробітник

Харківського національного університету

Повітряних Сил ім. І. Кожедуба,

Харків, Україна

https://orcid.org/0000-0001-9808-8319

\section{Ситник Юрій Борисович}

кандидат технічних наук

завідувач кафедри Льотної академії

Національного авіаційного університету,

Кропивницький, Україна

https://orcid.org/0000-0003-0966-691X

\section{Могилатенко Андрій Станіславович}

кандидат технічних наук

слухач

Національного університету оборони

України ім. І. Черняховського,

Київ, Україна

https://orcid.org/0000-0003-3905-0163

\section{Information about the authors:}

\author{
Aleksii Nikiforov \\ $\mathrm{PhD}$ in Engineering Senior Researcher \\ Lead Researcher \\ of Ivan Kozhedub Kharkiv \\ National Air Force University, \\ Kharkiv, Ukraine \\ https://orcid.org/0000-0002-0207-5175
}

\section{Serhii Smyk}

$\mathrm{PhD}$ in Engineering

Senior Researcher

of Ivan Kozhedub Kharkiv

National Air Force University,

Kharkiv, Ukraine

https://orcid.org/0000-0001-8941-2631

Pavlo Martynenko

Senior Researcher

of Ivan Kozhedub Kharkiv

National Air Force University,

Kharkiv, Ukraine

https://orcid.org/0000-0001-9808-8319

Yuriy Sytnyk

$\mathrm{PhD}$ in Engineering

Head of the Department

of Flight Academy of National Aviation University,

Kropyvnytzkyy, Ukraine

https://orcid.org/0000-0003-0966-691X

Andrii Mogilatenko
PhD in Engineering
Post-Graduate
of Ivan Chernyakhovsky National
Defense University of Ukraine, Kyiv,
Ukraine
https://orcid.org/0000-0003-3905-0163

Andrii Mogilatenko

$\mathrm{PhD}$ in Engineering

Post-Graduate

of Ivan Chernyakhovsky National

Ukraine

https://orcid.org/0000-0003-3905-0163

\section{РАСЧЁТ ДАЛЬНОСТИ ПОЛЁТА САМОЛЁТОВ С ТУРБОРЕАКТИВНОЙ СИЛОВОЙ УСТАНОВКОЙ ПРИ СОКРАЩЁННОМ НАБОРЕ ИСХОДНЫХ ДАННЫХ}

А.В. Никифоров, С.И. Смик, П.Н. Мартиненко, Ю.Б. Ситник, А.С. Могилатенко

В статье представлена методика расчёта тактического радиуса действия самолётов с турбореактивной силовой установкой на основе их лётно-технических характеристик, которые имеются в общедоступной справочной литературе. Это позволяет для расчета тактического радиуса не использовать громоздкие данные, содержащиеся в но- 
мограммах по расчёту дальности и продолжительности полёта самолётов соответствующих типов. При этом обеспечивается совпадение результатов расчетов, полученных с помощьью предлагаемой методики, с результатами, полу-

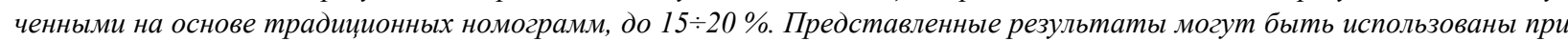
разработке специиального программного обеспечения для систем моделирования боевых действиий авиации.

Ключевые слова: инженерно-цтурманский расчёт, тактический радиус, профиль полёта, досягаемость авиации, дальность и продолжстельность полёта, километровый расход топлива, часовой расход топлива.

\section{CALCULATION OF THE TACTICAL RANGE OF AIRCRAFT WITH A TURBOJET POWER PLANT BASED ON A REDUCED SET OF INITIAL DATA}

A. Nikiforov, S. Smyk, P. Martinenko, Yu. Sytnyk, A. Mogilatenko

The article presents a method for calculating the tactical range of aircraft with a turbojet power plant based on their flight performance, given in public reference literature. Engineering and navigational calculations (ENC) occupy a significant place in the decision-making processes on the organization of the functioning and direct management of the functioning of aviation. The tasks to be solved within the framework of the ENC include: marking and checking the feasibility of flight routes in terms of fuel supply, calculating the tactical radii of aviation operations. Usually, to solve these problems, methods are used based on nomograms based on the calculation of the range and duration of aircraft flights. Nomograms are compiled based on the results of flight tests of various types and modifications of aviation equipment. To automate the ENC, they resort to the digitization of nomograms of the range and duration of the flight, which is associated with a significant investment of time. One has to deal with a large amount of initial data in order to turn them into a form convenient for automated calculations. Moreover, for each type or modification of the aircraft, these data are different. This greatly complicates the process of automating the ENC, which is due to the significant and time-consuming task of adding flight range and duration characteristics for each new type of aircraft. The article describes a technique for calculating the tactical range of aircraft with a turbojet power plant for an arbitrarily given profile of their flight and for various payload options, if not a nomogram is used as the initial data, but only the publicly available flight performance characteristics of these aircraft. The results of calculations are given for some types of aircraft with a turbojet power plant for different flight profiles and different payload options. The calculated data obtained for the L-39 aircraft are compared with the control results from the calculation of the tactical radius obtained on the basis of the Flight Operation Manual for this aircraft. This ensures the convergence of the results obtained using the proposed method with the results obtained on the basis of traditional nomograms, up to $15 \div 20 \%$. The presented results can be used in the development of special software for systems of simulation combat do aviation.

Keywords: engineering and navigational calculation, tactical radius, flight profile, reach of aviation, range and duration of flight, kilometer fuel consumption, fuel consumption per hour. 